\title{
Pelatihan pembelajaran efektif berbasis TSAC bagi guru sekolah dasar di Jawa Tengah
}

Arief Cahyo Utomo ${ }^{1, *}$, Ajib Rosyadi ${ }^{1}$, Amelia Wahyu Sejati ${ }^{1}$, Frida Fembriani Candradewi ${ }^{1}$, Muhammad Rasyid Affandi ${ }^{1}$, Muhamad Taufik Hidayat ${ }^{1}$, Muhroji ${ }^{1}$

${ }^{1}$ PGSD, Universitas Muhammadiyah Surakarta, Jalan Ahmad Yani No 1, Pabelan, Kartasura, Surakarta, Indonesia

*) Korespondensi (e-mail: acu234@ums.ac.id )

Received: 01-June-21; Revised: 20-June-21; Accepted: 23-June-21

\begin{abstract}
The purpose of this community service is to provide an effective teaching training based on TSAC (Teaching Skill Assessment Checklists) for elementary school teachers in Central Java. The strategic and appropriate targ et audience involved in th is activity were elementary school teachers in Central Java as many as 20 persons (Surakarta, Klaten, Karanganyar, Demak, Sragen, Brebes). The service materials are as follows: (1) Creating a supportive and warm classroom climate (2) Using waiting time during questions (3) Arranging content for effective presentations (4) Assessing, commenting, and discussing homework (5) Multitasking. A question-and-answer session was held and a discussion on the problems en countered in the field. After that, to determine the success of the implementation of this activity, an evaluation is carried out at the end of the implementation of the activity. The results of the implementation showed that the participants were very enthusiastic in participating the training. From the results of the question and answer, there are also many problems that exist in the elementary school in Central Java.
\end{abstract}

Keywords: Effective Teaching, Teachers, Elementary School

\begin{abstract}
Abstrak
Tujuan dari kegiatan pengabdian ini yaitu memberikan pelatihan pembelajaran efektif berbasis TSAC (Teaching Skill Assessment Checklists) bagi guru SD di Jawa Tengah. Khalayak sasaran yang strateg is dan tepat dilibatkan dalam kegiatan ini adalah guru SD di Jawa Tengah sebanyak 20 orang (Surakarta, Klaten, Karan ganyar, Demak, Sragen, Brebes ). Adapun materi pengabdian yaitu sebagai berikut: (1) Menciptakan iklim kelas yang mendukung dan hangat (2) Menggunakan waktu tunggu selama bertan ya (3) Mengatur konten un tuk presentasi yang efektif (4) Menilai, meng omentari, dan men diskusikan pekerjaan rumah (5) Mampu melakukan beberapa hal dalam satu waktu. Selanjutnya dilakukan sesi tan ya jawab dan diskusi mengenai permasalahan-permasalahan yang dijumpai di lapangan. Setelah itu, untuk mengetahui keberhasilan pelaksanaan kegiatan ini, dilakukan evaluasi di akhir pelaksanaan kegiatan. Hasil dari pelaksanaan menunjukkan bahwa peserta pengabdian sangat antusias dalam mengikuti kegiatan pelatihan. Dari hasil tanya jawab juga banyak menggali permasalahan yang ada di lapangan SD di Jawa Tengah.

Kata kunci: Pembelajaran Efektif, Guru, Sekolah Dasar

How to cite: Uto mo, A. C., Rosyadi, A., Sejati, A. W., Cand radewi, F. F., Affan di, M. R., Hidayat, M. T., \& Muhroji, M. (2021). Pelatihan pembelajaran efektif berbasis TSAC bagi Guru sekolah dasar di Jawa Tengah. Penamas: Journal of Community Service, 1(1),18-31.
\end{abstract}

\section{Pendahuluan}

Guru dan proses pembelajaran merupakan dua hal yang memiliki keterkaitan sangat erat dan mutlak. Artinya guru akan lebih memiliki makna secara edukatif jika guru itu 
mampu melakukan proses pembelajaran yang baik, tepat, akurat, serta relevan dengan fungsi dan prinsip pendidikan. Untuk mewujudkan idealisme pendidikan itu tidak cukup diimbangi dengan pembelajaran yang efektif. Sebagian besar siswa ada yang memiliki kebencian kepada salah satu mata pelajaran tertentu karena mata pelajaran yang dianggapnya sangat sulit dan begitu menakutkan. Entah karena dari faktor guru maupun faktor siswa yang malas untuk berusaha untuk bisa memahami materi pelajaran yang sedang dihadapinya. Selain itu, pembicaraan dari kakak kelas atau teman yang memberi informasi kepada siswa tersebut kalau materi pelajaran tersebut sulit, secara tidak langsung hal itu membuat semangat siswa menurun. Jika sang guru tidak dapat mendekati siswa yang kurang bersemangat, maka siswa tersebut selamanya akan berputus asa.

Dengan demikian, dalam proses belajar mengajar, seorang guru tidak hanya memiliki pengetahuan untuk diberikan kepada murid-muridnya. Tetapi guru dituntut untuk memilki kemampuan untuk memanage atau mengelola kelas baik secara fisik maupun kelas dalam artian siswa di kelas, ketika guru dapat mengelola kelas, maka akan tercipta suasana kelas yang kondusif sehingga mendukung kegiatan belajar mengajar yang efektif.

Untuk mengukur pengajaran yang efektif, peneliti (Devine et al., 2013; Liu \& Meng, 2009; Munoz et al., 2011; Stronge.J, 2018; Stronge, 2013; Stronge et al., 2007; Williams, 2010) telah mengeksplorasi kategori dan tema berbasis empiris dari berbagai negara. Di antara eksplorasi ini, kerangka kerja Stronge et al., (2007) pengajaran yang efektif telah diterapkan dengan baik dan diperkenalkan di AS dan di masyarakat Timur (L. Grant et al., 2014; L. W. Grant et al., 2013).

Pembelajaran yang efektif telah menjadi topik hangat dalam pendidikan internasional selama beberapa dekade terakhir. Setidaknya ada dua faktor yang merangsang agenda penelitian ini terkait dengan pengajaran yang efektif. Salah satu faktornya adalah studi internasional berskala besar seperti Tren Studi Matematika dan Sains Internasional (TIMSS) dan Programme for International Student Assessment (PISA). Hasil tes ini mengungkapkan bahwa siswa di Indonesia memiliki skor literasi, sains, dan matematika di bawah rata-rata. Bahkan pada tahun 2018, skor rata-rata Indonesia cenderung menurun.

Berdasarkan hasil TSAC (Teaching Skill Assessment Checklists atau survei kualitas pembelajaran efektif pada 117 guru sekolah dasar (SD) di Jawa Tengah, menunjukkan ada beberapa aspek dari pembelajaran efektif TSAC memiliki skor yang belum maksimal. Hal ini berarti, guru-guru di Jawa Tengah masih menilai diri memiliki kekurangan pada aspek pembelajaran tersebut. Adapun poin-poin tersebut yaitu sebagai berikut:

1. Dalam aspek Kepribadian Guru, nilai terendah berada di poin " menciptakan iklim kelas yang mendukung dan hangat".

2. Dalam aspek Manajem en Kelas nilai terendah pada poin "menggunakan waktu tunggu selama bertanya".

3. Dalam aspek Perencanaan Pembelajaran nilai terendah pada poin "mengatur konten untuk presentasi yang efektif ". 
4. Dalam aspek Menerapkan Instruksi nilai terendah pada poin "mampu melakukan beberapa hal dalam satu waktu".

5. Dalam aspek Memantau Kemajuan Potensi Siswa, nilai terendah pada poin "Menilai, mengomentari, dan mendiskusikan pekerjaan rumah di kelas".

Berdasarkan paparan di atas jelas bahwa ada beberapa hal yang berkaitan dengan pembelajaran efektif harus diberikan perhatian dan tindakan. Perhatian dan perbaikan poin-poin pembelajaran efektif pada guru SD, akan meningkatkan hasil belajar siswa SD termasuk skor PISA dan TIMSS. Oleh karenanya perlu upaya peningkatan kemampuan guru-guru SD di Jawa Tengah dalam poin-poin pembelajaran efektif tersebut.

Dari analisis situasi di atas jelas guru-guru SD di Jawa Tengah mengalami penilaian diri yang tidak optimal pada beberapa poin pembelajaran efektif. Guru-guru SD di Jawa Tengah perlu diberikan wawasan tentang poin-poin pembelajaran efektif dan bagaimana menerapkannya. Kegiatan pelatihan terkait poin-poin pembelajaran efektif terutama yang dirasa belum maksimal perlu diberikan kepada guru-guru SD di Jawa Tengah sebagai bekal pembelajaran. Dari latar belakang di atas, maka rumusan permasalahan yang dapat ditarik adalah bagaimana program pelatihan pembelajaran efektif berbasis TSAC bagi guru SD di Jawa Tengah?

Adapun tujuan yang ingin dicapai melalui kegiatan pengabdian ini adalah memberikan pelatihan pembelajaran efektif berbasis TSAC bagi guru SD di Jawa Tengah. Hasil kegiatan pengabdian pada masyarakat ini akan memberikan kontribusi positif terhadap usaha peningkatan kualitas pendidikan, khususnya di jenjang SD. Secara eksplisit kontribusi hasil kegiatan pengabdian masyarakat ini dapat dijabarkan sebagai berikut.

1. Para guru SD di Jawa Tengah memperoleh pendalaman pengetahuan poin-poin pembelajaran efektif sehingga dapat meningkatkan kemampuan pada aspek pembelajaran yang belum maksimal.

2. Peningkatan kompetensiguru SD di Jawa Tengah pada poin-poin pembelajaran efektif yang belum maksimal berdasarkan TSAC.

\section{Metode Pengabdian}

\section{Khalayak Sasaran}

Muara dari kegiatan ini adalah untuk meningkatkan kompetensi poin-poin pembelajaran efektif guru SD di Jawa Tengah. Terkait dengan hal ini, khalayak sasaran yang strategis dan tepat untuk dilibatkan dalam kegiatan ini adalah guru SD di Jawa Tengah sebanyak 20 orang.

\section{Tahap Persiapan}

Tujuan yang ingin dicapai melalui kegiatan pengabdian ini adalah memberikan pelatihan pem belajaran efektif berbasis TSAC bagi guru SD di Jawa Tengah. Adapun rincian rencana pelaksanaan sosialisasi program pelatihan ini sebagai berikut:

Waktu : Minggu, 13 Juni 2021

Tempat : Virtual Meeting dengan Tautan meet.google.com/bus-chcd-czd. 
Materi :

Peserta : Guru SD di Jawa Tengah

1) Menciptakan iklim kelas yang mendukung dan hangat

2) Menggunakan waktu tunggu selama bertanya

3) Mengatur konten untuk presentasi yang efektif

4) Menilai, mengomentari, dan mendiskusikan pekerjaan rumah

5) Mampu melakukan beberapa hal dalam satu waktu.

Bahan yang dibutuhkan antara lain:

1) Materi tentang menciptakan iklim kelas yang mendukung dan hangat

2) Materi tentang menggunakan waktu tunggu selama bertanya

3) Materi tentang mengatur konten untuk presentasi yang efektif

4) Materi tentang menilai, mengomentari, dan mendiskusikan pekerjaan rumah

5) Materi tentang mampu melakukan beberapa hal dalam satu waktu.

\section{Tahap Pelaksanaan}

Persiapan alat dan bahan selama pelatihan berlangsung, perlu dipersiapkan alat dan bahan. Alat yang digunakan adalah materi, alat tulis, laptop/handphone, koneksi Internet.

\section{Pelatihan Pembelajaran Efektif Berbasis TSAC}

Pelatihan ini terbagi dalam sekali pertemuan dalam Virtual Meeting dengan Tautan meet.google.com/bus-chcd-czd, Tema dalam tiap pertemuan tertera dalam tabel berikutini.

Tabel 1 Pelaksanaan Pelatihan Pembelajaran Efektif Berbasis TSAC

\begin{tabular}{cl}
\hline No, & \multicolumn{1}{c}{ Materi Kegiatan } \\
\hline 1 & Materi Umum (Sambutan, Selayang Pandang, dan Pengantar Materi) \\
\hline 2. & PEMBERIAN MATERI \\
1) Menciptakan iklim kelas yang mendukung dan hangat \\
2) Menggunakan waktu tunggu selama bertanya \\
3) Mengatur konten untuk presentasi yang efektif \\
4) Menilai, mengomentari, dan mendiskusikan pekerjaan rumah \\
5) Mampu melakukan beberapa hal dalam satu waktu. \\
\hline 3 & Evaluasi dan Tanya Jawab \\
\hline 4 & Penutup
\end{tabular}

\section{Evaluasi Pelaksanaan Program}

Pada sesi ini dilakukan tanya jawab atau diskusi mengenai permasalahanpermasalahan yang dijumpai di lapangan. Setelah itu untuk mengetahui keberhasilan pelaksanaan kegiatan ini, dilakukan evaluasi di akhir pelaksanaan kegiatan, Untuk mengukur keberhasilan kegiatan pengabdian maka diadakan evaluasi.

\section{Hasil Pengabdian}

\section{Sambutan Pengabdian}

Sambutan yang diberikan oleh Arif Cahyo Utomo, M.Pd memberikan sambutan kepada semua peserta yang hadir dalam pertemuan virtual Google meeting tentang pelatihan pembelajaran efektif. Menyampaiakan tentang pengucapan terimakasih sudah bersedia ikut serta dalam pelaksanaan virtual melalui google meeting tentang pelatihan pembelajaran efektif, beliau juga menyampaikan bahwa peserta yang hadir 
dalam virtual meeting diminta untuk memperhatikan dan meyampaikan permasalahanpermasalahan yang timbul di tem pat mengajar yang dialami oleh setiap peserta.

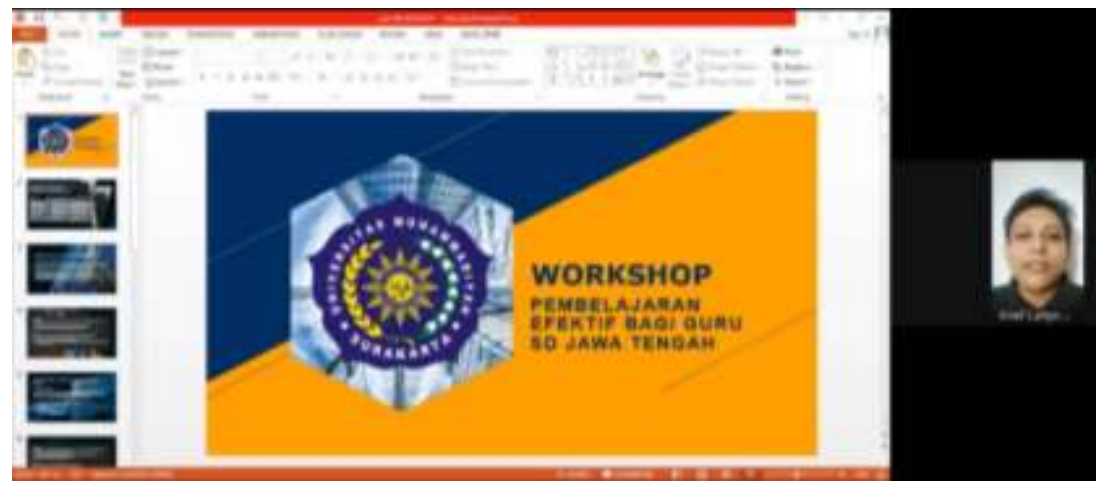

Gambar 1. Sambutan Pengabdian

\section{Selayang pandang dan Pengantar Materi}

Selayang pandang dan Pengantar materi yang diberikan oleh Muhamad Taufik Hidayat, M.Pd beliau menyampaikan tentang asal mula dilaksakan pelatihan pembelajaran efektif untuk guru sekolah dasar, beliau memaparkan bahwa asal mula pelatihan ini dimulai dari hasil penelitian tentang Persepsi diri Guru SD tentang Pengajaran yang Efektif, beliau juga menyampaikan bahwa dalam penelitian itu menggunakan teknik pengumpulan data menggunakan kuesioner yang diadopsiuntuk penelitian ini adalah Teacher Skills Assesment Checklists (TSAC) (Stronge 2007).

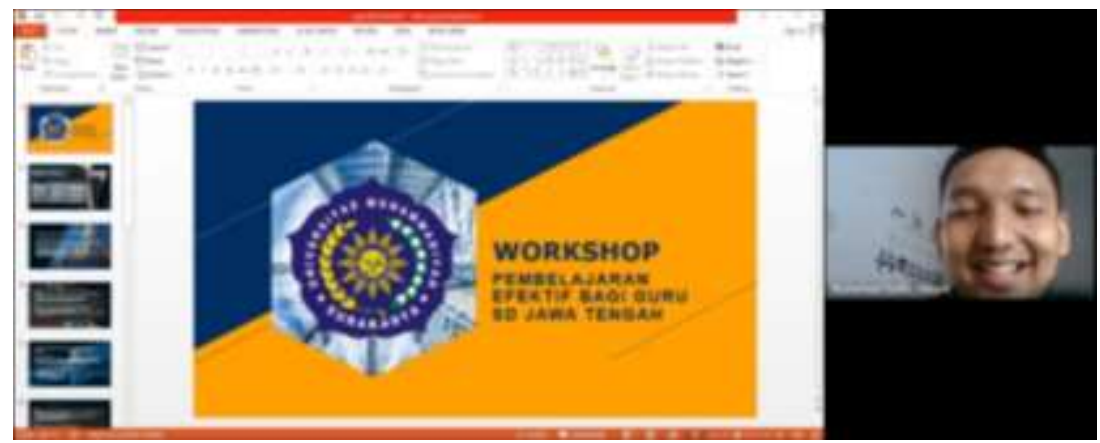

Gambar 2. Selayang Pandang dan Pengantar Materi

TSAC telah diterapkan di beberapa studi kuantitatif di seluruh dunia dalam efektivitas guru. Survei ini memiliki tiga bagian. Pada bagian I, peserta diminta untuk mengisi informasi umum termasuk jenis kelamin, tahun pengalaman mengajar, dan lokasi sekolah. Bagian II, peserta dim inta untuk mengevaluasi sendiri indikator kualitas guru dalam lima kategori yang diilustrasikan: (1) guru sebagai pribadi dengan 28 pertanyaan (2) manajemen kelas dan organisasi dengan 15 pertanyaan, (3) perencanaan pengajaran dengan 14 pertanyaan, (4) menerapkan instruksi dengan 19 pertanyaan, dan (5) memantau kemajuan siswa dengan 10 pertanyaan

\section{Menciptakan iklim kelas yang mendukung dan hangat}

Iklim kelas adalah sebuah konsep yang luas, mencakup mood (suasana perasaan) atau atmosfer yang diciptakan oleh guru kelas melalui aturan-aturan yang ditetapkan, cara guru berinteraksi dengan murid, dan bagaimana lingkungan fisik dikelola. Iklim kelas diarahkan untuk mewujudkan suasana kelas yang kondusif dan menyenangkan agar dapat memotivasi peserta didik untuk dapat belajar dengan baik sesuai dengan 
perkembangan dan kemampuannya. Jadi, Peranan guru di dalam kelas haruslah mampu menciptakan iklim kelas yang menarik, aman, nyaman dan keberadaannya di tengah-tengah siswa mampu mencairkan suasana, kebosanan, kejenuhan siswa saat dalam pembelajaran. Iklim kelas yang tidak kondusif akan berdampak negatif terhadap proses pembelajaran dan sulitnya tercapai tujuan pembelajaran, siswa akan merasa gelisah, resah, bosan dan jenuh. Sebaliknya dengan iklim kelas yang kondusif dan menarik dapat dengan mudah mencapai tujuan pembelajaran, dan proses pembelajaran yang dilakukan menyenangkan bagi peserta didik.

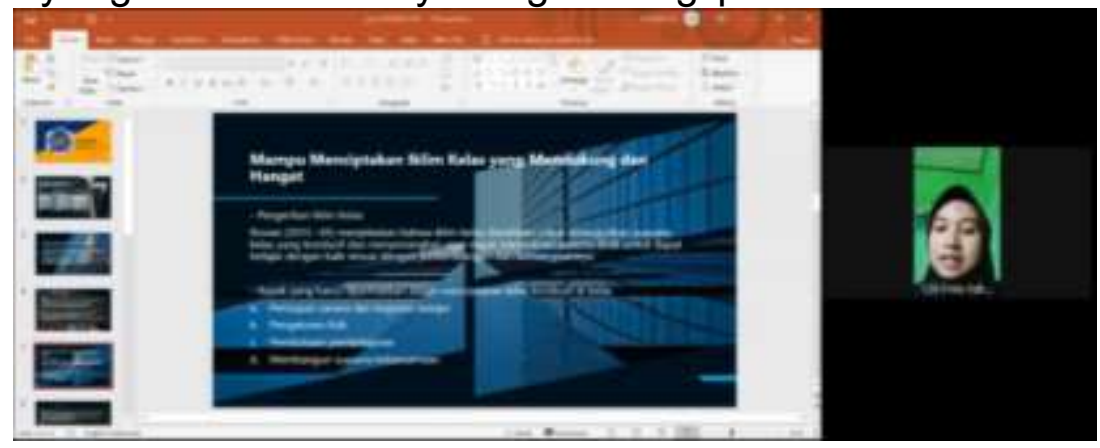

Gambar 3. Materi Menciptakan Iklim Kelas yang Mendukung dan Hangat

Dalam pembelajaran, yang perlu diperhatikan oleh guru SD dalam menciptakan lingkungan belajar yang kondusif, yaitu: (1) persiapan sarana dan kegiatan belajar; (2) pengaturan fisik; (3) pembukaan pelajaran; (4) membangun suasana kebersamaan.

Hambatan yang biasanya dihadapi guru SD dalam menciptakan iklim kelas yang mendukung dan hangat, yaitu : (1) suasana pembelajaran masih belum cukupkondusif, karena dalam pembelajaran masih ada siswa yang gaduh, berbicara dengan teman lainnya dan kurang memperhatikan guru saat menjelaskan; (2) rata-rata luas ruang kelas masih kurang 5 jika dibanding dengan jumlah siswa yang banyak; (3) ketersedian media dan alat peraga masih kurang; (4) guru biasanya hanya menggunakan alat peraga secara tradisional belum semua sekolah menggunakan teknologi seperti LCD.

Solusi yang bisa dilakukan untuk mengatasi hambatan yang dihadapi guru SD yaitu sebagai berikut: (1) Menyampaikan aturan dengan tegas namun penuh empati (2) Bangun komunikasi yang baik dengan siswa dan orangtua (3) Libatkan siswa dalam membuat aturan (4) Amati dan pahami perilaku setiap siswa (5) Berikan dukungan siswa dalam belajar.

\section{Menggunakan waktu tunggu selama bertanya}

Proses bertanya pada pembelajaran mendorong terciptanya lingkungan pembelajaran yang berpusat dalam siswa (student-centered learning environment) sembari memelihara kegiatan yang serius.

Tujuan bertanya tidak sekadar buat memperoleh informasi, namun pula buat menaikkan kemampuan berpikir peserta didik. Dengan mengajukan pertanyaan pada proses pembelajaran, peserta didik dituntut buat menaruh respons berupa pengetahuan atau hal-hal yang adalah output pertimbangan menurut proses berpikir. Jadi bertanya dapat disimpulkan bahwa bertanya merupakan suatu keterampilan yang 
bertujuan untuk memperoleh informasi, meciptakan lingkungan pembelaharan yang lebih efektif, dan mem buat peserta didik mampu lebih berpikir kritis.

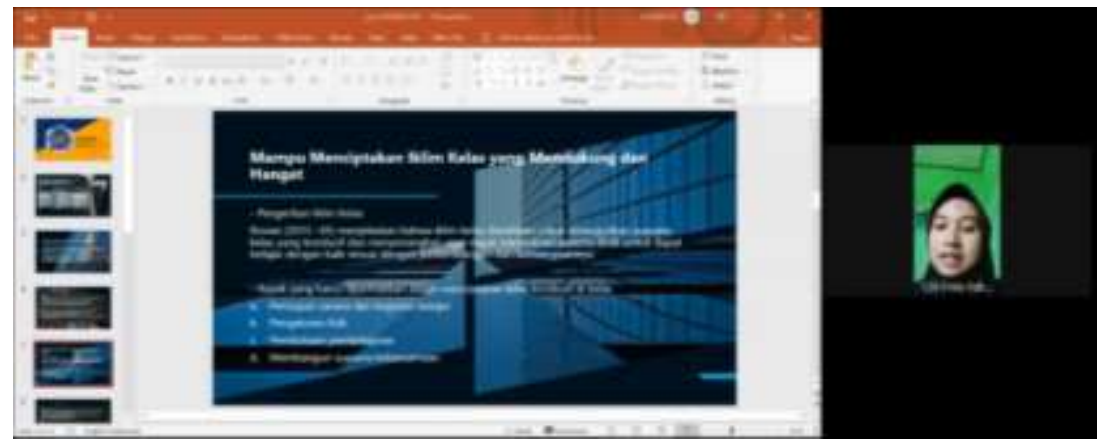

Gambar 4. Materi Menggunakan Waktu Tunggu Selama Bertanya

Dalam pem belajaran, guru SD dalam menggunakan waktu tunggu selama bertanya akan melakukan hal-hal sebagai berikut yaitu (1) Memberikan pertanyaan yang dianggap siswa mampu menjawab pertanyaan tersebut, (2) Guru dapat mengalihkan topik pembicaraan sembari menunggu siswa memikirkan jawaban dari pertanyaan tersebut, (3). Guru dapat memberikan pancingan clue atau kata kunci untuk jawaban tersebut.

Kesulitan yang dihadapi guru SD dalam menggunakan waktu tunggu selama bertanya yaitu: (1). Ketika seorang siswa yang mempunya sifat pesimis akan malu untuk mengemukakan jawaban. (2) Siswa yang kurang focus pada saat pembelajaran berlangsung. (3) Siswa yang tidak memperhatikan guru ketika guru menjelaskan materi sehingga ketika guru bertanya siswa tersebut tidak bisa menjawab dan menyebabkan memakan waktu yang banyak. (4) Kesulitan yang dihadapi seorang guru salanjutnya yaitu menjadi korupsi waktu haynya karena menunggunjawaban dari seorang siswa.

Solusi yang dapat dilakukan untuk mengatasi ham batan guru tersebut adalah (1) Mengunakan metode lain yang membuat siswa menjadi fokus ketika guru menjelaskan sehingga ketika guru memberikan pertanyaan kepada siswa tidak membuang-buang waktu yang lama untuk mendapatkan jawaban dari siswa tersebut, (2) Solusi selanjutnya yang dapat digunakan adalah dengan cara guru memberikan pertanyaan yangbsama kepada siswa yang lain sehingga guru medapatkan jawaban tersebut tanpa menunggu waktu yang sangat lama.

\section{Mengatur konten untuk presentasiyang efektif}

Berbicara adalah suatu penyampaian maksud ide, pikiran, isi hati seseorang kepada orang lain dengan menggunakan bahasa lisan sehingga maksud tersebut dapat dipahami orang lain. Dengan kata lain berbicara didepan khalayak um um khususnya di lingkup pendidikan disebut juga presentasi. Presentasi dapat dikatakan efektif ketika dibawakan dengan singkat namun padat informasi. Yang dimaksudkan presentasi yang efektif adalah presentasi yang mencapai tujuanya, yaitu ketika audiens melakukan apa yang diharapkan oleh presenter. Suatu presentasi bisa dikatakan sebagai presentasi yang efektif ketika Audiens tidak merasa bosan mendengarkan presentasi tersebut dan mendengarkan presentasi sampai selesai dengan antusias. 
Ketika banyak audiens yang mengantuk, lebih asyik dengan ponselnya saat mendengarkan presentasi, atau sebentar-sebentar melirik jam tangannya, itu sudah menjadi tanda bahwa presentasi tersebut tidak efektif. Cukup banyak isi presentasi yang diingat oleh para audiens. Itu artinya, audiens benar-benar mendengar dan menyimak presentasi yang disampaikan. Audiens tergerak untuk melakukan apa yang diharapkan oleh presenter yang menyampaikan presentasi. Tujuan dari presentasi dalam proses pembelajaran bermacam-macam, misalnya untuk memberi informasi, untuk meyakinkan peserta, menyampaikan pesan dan bahkan untuk melakukan penilaian

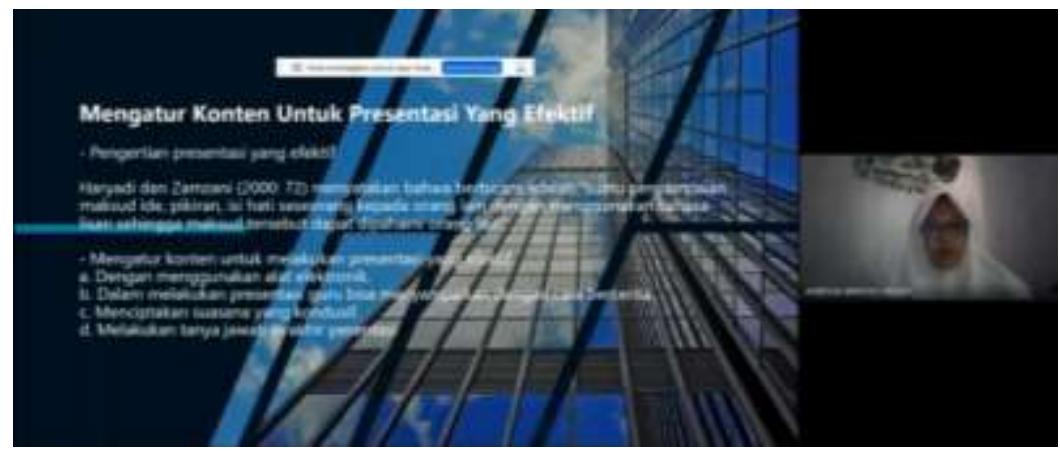

Gambar 5. Materi Mengatur Konten untuk Presentasi yang Efektif

Dalam pembelajaran, guru SD mengatur konten untuk melakukan presentasi yang efektif yaitu: (1) Dengan menggunakan alat elektronik dengan cara menampilkan presentasi dengan beberapa slide Power Point, yang berisi tulisan menarik, kata-kata singkat, gambar, efek animasi dan efek sound. (2) Dalam melakukan presentasi guru bisa menyampaikan dengan cara bercerita,dengan begitu siswa akan senang dan tidak merasakan jenuh (3). Sekreatif mungkin guru menciptakan suasana yang kondusif tetapi tidak begitu tegang agar siswa/audien tidak merasakan bosan. (4) Di akhir presentasi tersebut guru melakukan tanya jawab agar siswa yang telah mengikut dan mendengarkan bisa diaplikasikan dan bisa mengetahui seberapa fokus siswa mendengarkan presentasi tersebut.

Hambatan atau tantangan yang biasanya dihadapi guru saat mengatur konten untuk presentasi yang efektif yaitu: (1). Terjadinya trouble dan eror sistem ketika guru melakukan presntasi menggunakan alat elektronik. (2). Ketika sedang berlangsung presentasi banyak dari audien yang tidak fokus memperhatikan dan sibuk sendir bahkan bermain-main dengan teman yang ada disebelahnya. (3). Biasanya terjadinya perubahan waktu yang secara mendadak sehingga gugup dan tidak bisa maksimal saat melakukan presentasi sehingga apa yang disampaikan tidak maksimal. (4) Kurangnya penguasaan materi dan cakupan yang kurang luas.

Ada beberapa solusi yang dapat dilakukan untuk mengatasi hambatan yang dihadapi oleh guru SD sebagai berikut: (1). Jika pada saat melakukan presentasi terjadi eror dan torubelnya sistem dengan alternatifnya guru sebaiknya jangan menghabiskan waktu hanya untuk membereskan kendala tersebut tetapi dengan sigap meminta bantuan orang yang kiranya ada disamping sering disebutasistennya untuk menanggapinya dan guru tetap fokus melakukan presentasi. (2). Jika terjadi 
permasalahan kurangnya fokus audiens terhadap presentator, dengan bijak guru ada tindakan breaking atau melakukan permainan yang mengasah otak agar kembali bangun. (3). Terjadinya perubahan waktu yang secara tiba-tiba guru bisa atasi dengan membuat key word/kata kunci dalam slide presentasi. Kata kunci digunakan untuk mengatur runtutan presentasi, juga bisa dilakukan untuk membuat skala prioritas. (4). Penguasaan materi dalam presentasi merupakan hal penting sebagai presentator. Jika terjadi kurangnya penguasaan materi sebaiknya guru bertindak kemedia yang berfungsi sebagai alat bantu presntasi. Bukan sebagai sumber satu-satunya presentasi. Sebagai presentator tetap memegang peranan yang sangat penting untuk menjelaskan materi-materi yang hendak disam paikan.

\section{Menilai, mengomentari, dan mendiskusikan pekerjaan rumah}

Nilai adalah suatu kegiatan mengam bil keputusan sebagai bentuk hasil belajar untuk menentukan sesuatu berdasarkan kriteria tertentu yang bersifat kualitatif berupa angka, objektif, dan nilai, sedangkan mengomentari memberikan suatu masukan saran yang mengarah pada perbaikan jawaban pekerjaan rumah yang di berikan, dan mendiskusikan suatu pengecekan apabila terjadi perbedaan pendapat sehingga mendapatkan satu jawaban yang di sepakati, pekerjaan rumah sendiri merupakan suatu tugas yang diberikan kepada siswa setelah suatu materi atau bahan ajar selesai diulas ataudiberikan di dalam pem belajaran, di harapkan dengan diberikan pekerjaan rumah siswa menjadi lebih paham terhadap materi yang diberikan, kegiatan seperti itu sangat penting bagi seorang guru, karena nilai merupakan apresiasi untuk siswa dan tahap akhir dalam pembelajaran adalah memberikan nilai apabila siswa sudah memenuhi kriteria.

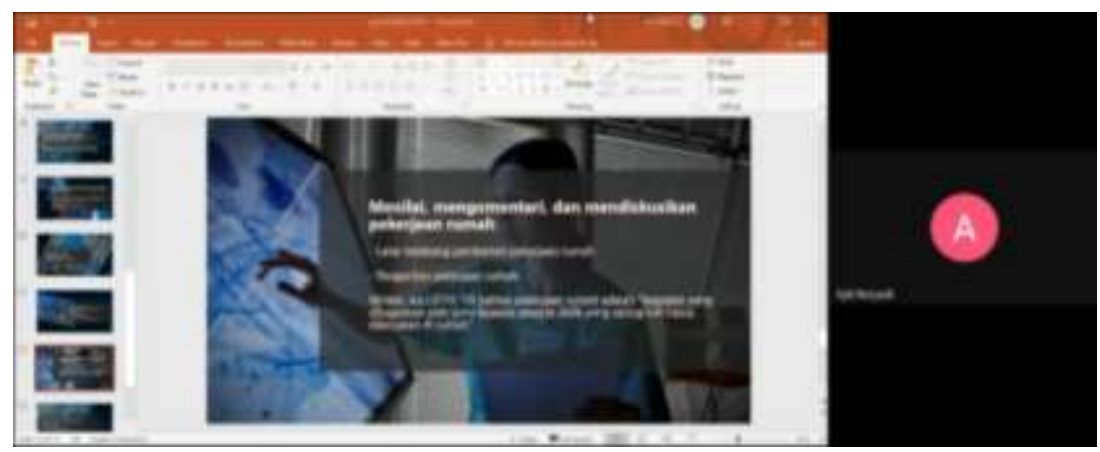

Gambar 6. Materi Menilai, Mengomentari, dan Mendiskusikan Pekerjaan Rumah

Contoh penerapan dari menilai, mengomentari, dan mendiskusikan pekerjaan rumah yang dapat dilakukan guru SD yaitu:

1. Memberikan nilai atas pekerjaan siswa yang telah dikerjaan sesuai dengan kriteria

2. Mengoreksi pekerjaan sebelum memberikan nilai pada siswa

3. Melakukan musyawarah dengan antar pendidik apabila menemukan perbedaan jawaban

4. Mengadakan pembahasan soal yang telah dijadikan pekerjaan rumah

5. Mengulas materi bahan ajar untuk memaksimalkan pemahaman siswa 
Hambatan yang dirasakan sebagai guru SD mengenaimenilai, mengomentari, dan mendiskusikan pekerjaan rumah yaitu:

1. Apabila ada siswa yang terlambat mengumpulkan tugas atau tidak bersamaan dalam pengumpulan tugas

2. Siswa tidak menjawab keseluruhan tugas yang diberikan, hanya menjawab sebagian soal

3. Di masa pandemi seperti ini jaringan dan kuota menjadi hambatan juga

4. Jika dikelas kadang ada siswa yang susah memahami materi perlu diberi pemahaman tersendiri

5. Kurangnya pemahaman siswa terhadap tugas yang diberikan

6. Adanya perbedaan jawaban yang perlumengadakan diskusi untuk mendapat kesepakatan

Solusi yang dapat di tempuh guru SD dalam menangani masalah atau hambatan diatas adalah dengan mengulas kembali materi ajar, bisa juga membahas secara bersama dengan siswa mengenai pekerjaan rumah yang telah diberikan untuk memaksimalkan pemahaman siswa terhadap materi ajar atau bahan ajar, membuka forum diskusi tanya jawab agar siswa yang belum paham dapat bertanya dan diberi pemahaman oleh guru yang mengajar, dapat juga dengan membuat jadwal jam tambahan apabila siswa dan guru sama-sama setuju dan berkenan itupun jika materi yang diberikan benar-benar sulit dipahami para siswa.

\section{Mampu melakukan beberapa hal dalam satu waktu.}

Seseorang yang biasa melakukan beberapa hal atau beberapa pekerjaan dalam satu waktu biasa di namakan dengan orang yang multitasking. Kemampuan ini biasa terbentuk karena budaya pada kehidupan sehari-harinya. Namun seseorang yang melakukan dua tugas atau lebih pasti tugas-tugas tersebut saling berkaitan satu dengan yang lain agar tidak terlalu mencabangkan pikiran kita. Multitasking ini memiliki banyak manfaat di antaranya bisa menghemat waktu, sehingga semua pekerjaan bisa selesai dengan tepat waktu dalam sekali kerja. Namun ada juga kekurangan dari multitasking ini diantaranya rentan terjadi kesalahan karena jika akan melakukan multitasking harus memiliki tingkat focus yang tinggi dan ketelitian yang lebih.

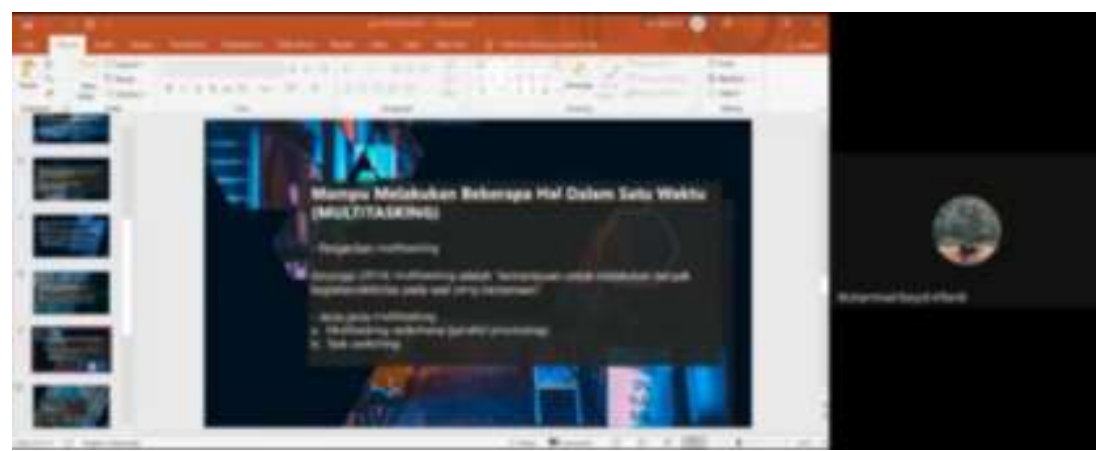

Gambar 7. Materi Mampu Melakukan Beberapa Hal dalam Satu Waktu.

Contoh penerapan kemampuan guru dalam melakukan beberapa hal pada satu waktu dalam kegiatan belajar mengajar khususnya padajenjang sekolah dasar adalah ketika guru sedang mengajar di kelas namun sang guru harus sembari mengerjakan tugas yang lain seperti membuat laporan pertanggungjawaban, mengoreksi tugas 
siswa, atau mengurus masalah yang lain dalam satu waktu. Kegiatan yang di lakukan secara bersamaan seperti ini tentu memiliki resiko serta tanggungjawab yang lumayan berat juga karena kita harus terus dan tetap focus dalam keadaan seperti apapun.

Hambatan atau kesulitan yang di alami guru dalam kemampuan melakukan beberapa hal dalam satu waktu atau multitasking antara lain adalah kadang merasa kurang focus apabila mengerjakan beberapa pekerjaan secara bersamaan. Selain itu hambatan apabila melakukan multitasking adalah keadaan peserta didik yang terkadang tidak bisa tenang atau malah rebut tidak mau diam. Selain menghambat kegiatan belajar mengajar di kelas ini juga bisa menganggu konsentrasi guru yang sedang menghendel beberapa pekerjaan secara bersamaan. Selain itu guru juga harus memberimateri yang jelas dan tugas agar bisa di tinggal mengerjakan pekerjaan yang lain tanpa ada gangguan dari peserta didik.

Beberapa solusi yang bisa dilakukan untuk mengatasi hambatan yang dihadapi guru SD dalam kemampuan melakukan beberapa hal dalam satu waktu antara lain (1) menkoordinasi siswa agar menciptakan suasana yang tenang dan nyaman. Tenang dan nyaman dalam hal ini adalah bagi siswa agar lebih fokus mengerjakan tugas atau memahami materi dan bagi guru agar fokus dalam melakukan pekerjaan nya. (2) memberikan alat bantu belajar bagi peserta didik agar lebih nyaman belajar dan tidak menganggu guru yang sedang mengerjakan tugas lain. (3) namun apabila memang tidak memungkinkan guru melakukan multitasking di sekolah, pekerjaan bisa di kerjakan di rumah untuk memaksimalkan kegiatan belajar mengajar di sekolah.

\section{Evaluasi dan Tanya Jawab}

Kegiatan evaluasi dan tanya jawab dilakukan antara pemberi materi dan peserta pelatihan yang dilaksanakan dalam pertemuan virtual google meet pada hari Minggu, 13 Juni 2021 dalam sesi tanya jawab terdapat 6 (enam) pertanyaan yang dilontarkan dari (1) Saudari A P guru di kota Klaten mem pertanyakan tentang cara mengendalikan kelas waktu mengerjakan tugas di luar sekolahan, (2) Saudari A W guru dari Solo mempertanyakan cara melatih siswa mandiri dalam pengerjaan tugas, (3) Saudara M A dari Karanganyar mempertanyakan cara membuat jadwal jika waktu datang bersamaan, (4) Saudari V F M guru dari Demak memberikan 2 pertanyaan tentang cara melatih siswa disiplin dalam mengumpulkan tugas, dan cara menghadapi siswa yang lambat belajar, dan (5) Saudari D N M guru dari Sragen mempertanyakan apakah guru kelas bisa merangkap menjadi guru bimbingan konseling.

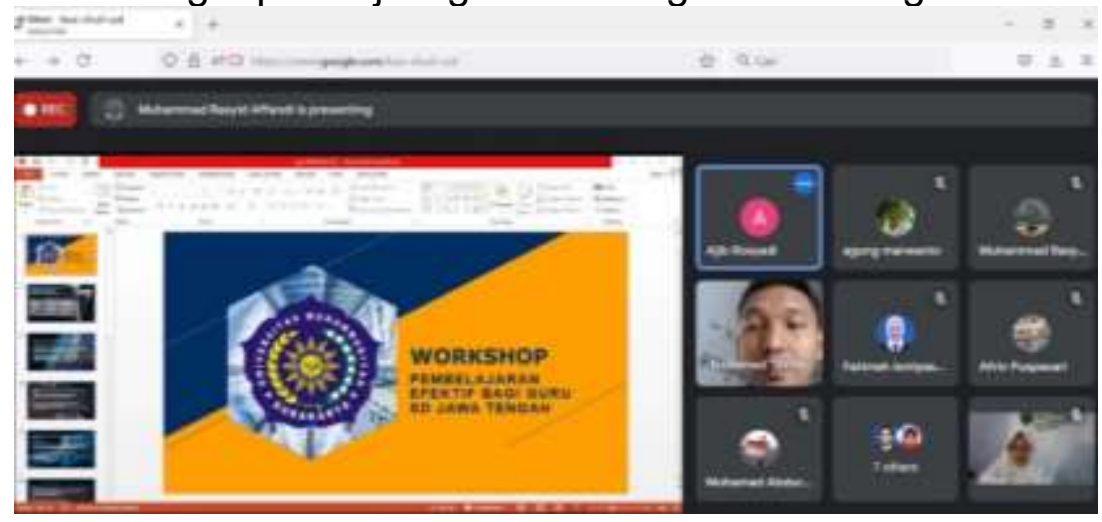

Gambar 8. Evaluasi dan Tanya Jawab 
Dalam sesi tanya jawab tersebut pertanyaan tentang cara mengendalikan kelas waktu mengerjakan tugas di luar sekolahan dijawab oleh Saudari F F memberikan solusi bahwa guru kelas lain untuk merangkap dan mengawasi kelas yang kosong, lalu moderator Saudara A R memberikan tambahan bahwa ditunjuk ketua kelas untuk mencatat kejadian di dalam kelas seperti ramai, keluar kelas dan mengganggu teman.

Pertanyaan kedua tentang cara melatih siswa mandiri dalam pengerjaan tugas dijawab oleh Saudari A W S menjawab siswa diberikan peringatan dan pengertian bahwa tugas harus dikerjakan sendiri lalu moderator Saudara A R menambahkan setiap pengerjaan tugas lebih baik disertakan pengiriman video saat pengerjaan tugas.

Pertanyaan ketiga tentang cara membuat jadwal jika waktu datang bersamaan dijawab oleh Saudara M RA bahwa lebih baik diutamakan yang penting terlebih dahulu.

Pertanyaan ke-empat dan kelima tentang cara melatih siswa disiplin dalam mengumpulkan tugas, dan cara menghadapi siswa yang lambat belajar dalam pertanyaan ini dijawab oleh Saudari F F bahwa diberikan peringatan kalau terlambah mengum pulkan tugas tidak mendapatkan nilai, lalu dijawab oleh Saudari A W S bahwa guru harus tegas dalam menghadapi siswa yang kurang disiplin, Saudari D N M memberikan jawaban lebih baik di dalam kelas diberikan papan prestasi, sehingga siswa lebih berlomba lagi dalam pengumpulan tugas, lalu moderator Saudara A R memberikan tambahan bahwa siswa yang kurang disiplin diberikan tanggungjawab yang lebih misalkan pengumpulan tugas di rumah siswa yang kurang disiplin, lalu pada jawaban menghadapi siswa yang lambat belajar maka guru harus menganalisis terlebih dahulu kendala apa saja yang dihadapi siswa maka didiskusikan dengan walimurid.

Pertanyaan ke-enam tentang apakah guru kelas bisa merangkap menjadi guru bimbingan konseling diberikan jawaban oleh Saudari A W S bahwa guru harus bisa menjadi guru bimbingan konseling dalam tujuan mengenali gejala-gejala dan tandatanda siswa yang kurang terhadap hasil belajar siswa.

\section{Kesimpulan}

Hasil dari pelaksanaan menunjukkan bahwa peserta pengabdian sangat antusias dalam mengikuti kegiatan pelatihan. Hasil tanya jawab juga banyak menggali permasalahan yang ada di lapangan SD di Jawa Tengah.

\section{Ucapan Terimakasih}

Ucapan terimakasih sebesar-besarnya penulis haturkan pada Universitas Muhammadiyah Surakarta yang telah memberikan dukungan dana dalam skema program Hibah Integrasi Tridharma FKIP 2021.

\section{Referensi}

Devine, D., Fahie, D., \& McGillicuddy, D. (2013). What is "good" teaching? Teacher beliefs and practices about their teaching. Irish Educational Studies, 32(1), 83108. https://doi.org/10.1080/03323315.2013.773228

Grant, L., Stronge, J., Xu, X., Popp, P., Sun, Y., \& Little, C. (2014). West meets east: 
Best practices from expert teachers in the U.S. and China.

Grant, L. W., Stronge, J. H., \& Xu, X. (2013). A cross-cultural comparative study of teacher effectiveness: Analyses of award-winning teachers in the United States and China. Educational Assessment, Evaluation and Accountability, 25(3), 251276. https://doi.org/10.1007/s11092-013-9170-1

Liu, S., \& Meng, L. (2009). Perceptions of teachers, students and parents of the characteristics of good teachers: A cross-cultural comparison of China and the United States. Educational Assessment, Evaluation and Accountability. https://doi.org/10.1007/s11092-009-9077-z

Munoz, M. A., Prather, J. R., \& Stronge, J. H. (2011). Exploring teacher effectiveness using hierarchical linear models: Student and classroom level predictors and cross year stability in elementary school reading. Planning and Changing.

Stronge.J. (2018). Effective teaching :what does it all mean? In Qualities of effective teachers.

Stronge, J. H. (2013). Effective teachers = student achievement: What the research says. Effective Teachers = Student Achievement: What the Research Says, 1173. https://doi.org/10.4324/9781315854977

Stronge, J. H., Ward, T. J., Tucker, P. D., \& Hindman, J. L. (2007). What is the relationship between teacher quality and student achievement? An exploratory study. Journal of Personnel Evaluation in Education. https://doi.org/10.1007/s11092-008-9053-z

Williams, R. E. (2010). Administrator and teacher perceptions of the qualities of effective teachers. In Education. https://doi.org/10.25774/w4-c9nn-kb54 